\title{
POLA TANAM PROPAGUL DAN BIBIT Rhizophora stylosa Griff. PADA TAPAK BERLUMPUR DI AREAL REHABILITASI MANGROVE DESA MENDALOK
}

(Propagul Plant Patterns and Seeds Rhizophora stylosa Griff. on Muddy Site in Mangrove Rehabilitation Area of Mendalok Village)

\author{
Riza Nopinilianti ${ }^{1)}$, Burhanuddin ${ }^{2)}$, M. Sofwan Anwari ${ }^{2)}$ \\ ${ }^{1)} \mathrm{KPH}$ Wilayah Mempawah, Jalan Raden Kusno Mempawah 78912, Indonesia \\ ${ }^{2)}$ Fakultas Kehutanan Universitas Tanjungpura, Jalan Imam Bonjol 78124, Indonesia \\ email: riza_astri@yahoo.com
}

\begin{abstract}
Propagul plant patterns and seeds Rhizophora stylosa Griff.on muddy site in mangrove rehabilitation area of Mendalok Village. This study aims to find the source of sapling and appropriate cropping pattern on the muddy site in mangrove rehabilitation area Mendalok Village. Research using factorial complete design with four treatment combinations, namely $A_{l} B_{1}$ (Seeds $R$. stylosa with square plant patterns/ $1 m \times 1 \mathrm{~m}$ ), $A_{l} B_{2}$ (Seeds R. stylosa with cluster plant pattern / $0.2 \mathrm{~m} \times 0.5 \mathrm{~m}$ ), $A_{2} B_{1}($ Propagul R. stylosa with square plant patterns) and $A_{2} B_{2}$ (Propagul $R$. stylosa with cluster plant pattern). Each treatment was repeated 5 times. The results showed that the source of saplings (propagules and seeds) have a significant effect on living percentage and have a very real effect on the high growth, diameter and number of $R$. stylosa leaves. Treatment planting pattern (square and cluster) has not shown any real effectto live percent, high growth, diameter and number of leaves until age 4 months of planting. The results showed the best live percentage was shown by treatment $A_{2} B_{1}$ amounted to $69.33 \%$. The best high growth is the treatment of $A_{2} B_{2}$ which is $13.94 \mathrm{~cm}$. The best diameter growth is the treatment of $A_{1} B_{1}$ and $A_{1} B_{2}$ is $0.54 \mathrm{~cm}$. The best growth of leaf number is treatment $A_{l} B_{l}$ ie 8.48 strands. The soil at the research site is a muddy substrate with a dust texture of $60.44 \%, 38.02 \%$ clay and $1.54 \%$ sand. Propagules and R. stylosa seedlings can grow well if they are able to adapt to ocean currents.
\end{abstract}

Keywords: cluster, muddy substrate, propagule, Rhizophora stylosa, square

Abstrak

Pola tanam propagul dan bibit Rhizophora stylosa Griff. pada tapak berlumpur di areal rehabilitasi mangrove Desa Mendalok. Penelitian ini bertujuan untuk menemukan sumber anakan dan pola tanam yang sesuai pada tapak berlumpur di areal rehabilitasi mangrove Desa Mendalok. Penelitian menggunakan rancangan factorial Rancangan Acak Lengkap dengan 4 kombinasi perlakuan, yaitu $A_{1} B_{1}$ (Bibit $R$. stylosa dengan pola tanam bujursangkarl $1 \mathrm{~m} \times 1 \mathrm{~m}$ ), $A_{1} B_{2}$ (Bibit $R$. stylosa dengan pola tanam cluster/ 0,2 $m \times 0,5 \mathrm{~m}$ ), $A_{2} B_{1}$ (Propagul $R$. stylosa dengan pola tanam bujursangkar) dan $A_{2} B_{2}$ (Propagul R. stylosa dengan pola tanam cluster). Setiap perlakuan diulang sebanyak 5 kali. Hasil penelitian menunjukkan perlakuan sumber anakan (propagul dan bibit) berpengaruh nyata bagi persen hidup dan berpengaruh sangat nyata pada pertumbuhan tinggi, diameter dan jumlah daun R. stylosa. Perlakuan pola tanam (bujursangkar dan cluster) belum menunjukkan pengaruh nyata terhadap persen hidup, pertumbuhan tinggi, diameter dan jumlah daun sampai umur 4 bulan penanaman. Hasil penelitian menunjukkan persen hidup terbaik ditunjukkan oleh perlakuan $A_{2} B_{1}$ sebesar 69,33\%. Pertumbuhan tinggi terbaik adalah perlakuan $A_{2} B_{2}$ yaitu sebesar 13,94 cm. 
Pertumbuhan diameter terbaik adalah perlakuan $A_{1} B_{1}$ dan $A_{1} B_{2}$ yaitu $0,54 \mathrm{~cm}$. Pertumbuhan jumlah daun terbaik adalah perlakuan $A_{1} B_{1}$ yaitu 8,48 helai. Tanah di lokasi penelitian merupakan substrat berlumpur dengan tekstur debu 60,44\%, liat 38,02 \% dan pasir 1,54\%. Propagul dan bibit R. stylosa dapat tumbuh dengan baik jika mampu beradaptasi terhadap arus laut.

Kata kunci : bujur sangkar, cluster, propagul, Rhizophora stylosa, substrat berlumpur,

\section{PENDAHULUAN}

Ekosistem mangrove sangat viabel, mangrove yang rusak mampu memulihkan diri jika faktor-faktor lingkungan mendukung seperti pola hidrologi, kondisi tanah dan ketersediaan propagul (Setyawan et al, 2004). Propagul merupakan buah/ benih dari beberapa jenis mangrove yang berbentuk silinder dan mulai berkecambah ketika masih berada pada pohon induk (Kustanti, 2011). Apabila faktor lingkungan tersebut tidak terpenuhi perlu regenerasi buatan melalui rehabilitasi mangrove. Rehabilitasi bertujuan memulihkan kembali fungsi hutan mangrove agar mendekati kondisi alaminya. Kesesuaian jenis sangat penting dalam upaya rehabilitasi mangrove pada kawasan yang rusak atau reforestasi pada tanah yang baru terbentuk (tanah timbul) di kawasan pesisir. Hal ini untuk memperkecil kemungkinan kegagalan. Rehabilitasi umumnya dengan penanaman jenis Rhizophora spp., salah satunya adalah Rhizophora stylosa Griff. Jenis ini merupakan spesies pioner di hutan mangrove yang memiliki arti penting dalam kestabilan hutan mangrove (Kusmana et al, 2011).

Keberhasilan rehabilitasi mangrove dipengaruhi banyak faktor, antara lain ketersediaan propagul (Kairo et al, 2001). R. stylosa termasuk kelompok Rhizopora spp yang memiliki buah vivivari. Propagul mulai berkecambah ketika masih berada di pohon, ketika propagul tersebut jatuh dan mendapatkan tempat yang cocok akan tumbuh dan berkembang.

Setyawan, et al (2004) menyebutkan jarak tanam juga berpengaruh dalam rehabilitasi mangrove yang akan menentukan kerapatan mangrove dan kekuatannya menghadapi gempuran ombak. Menurut Halidah (2009) jarak tanam memberikan pengaruh yang nyata terhadap persen tumbuh anakan Rhizophora mucronata Lam. Menurut Nybakken (1992), keberhasilan pertumbuhan mangrove dipengaruhi oleh tempat tumbuh/ substrat tanah.

Desa Mendalok Kabupaten Mempawah merupakan salah satu areal rehabilitasi mangrove di Kalimantan Barat. Hutan mangrove di Desa Mendalok ini merupakan tipe kajapah yaitu tipe hutan mangrove yang berbatasan langsung dengan laut. Terdapat areal tanpa vegetasi dengan substrat berlumpuryang potensial untuk ditanami mangrove. Areal tersebut merupakan tanah timbul yang berada di tepi pantai dan berbatasan langsung dengan laut. Daratan baruini terbentuk dari akumulasi lumpur yang terbawa arus pasang surut air laut.

Rehabilitasi mangrove telah dilakukan dengan penanaman mangrove jenis $R$. stylosa. Penanaman umumnya menggunakan sumber anakan berupa bibit. Rehabilitasi mangrove menggunakan bibit menunjukkan persentase keberhasilan yang rendah sehingga biasanya dilakukan penanaman propagul yang diikat bersama bibit. Propagul dan bibit diikat 
bersamaan pada ajir untuk setiap lubang tanamnya. Keberhasilan rehabilitasi dengan penanaman bibit dan propagul secara bersamaan menunjukkan persentase hidup lebih baik, sedangkan persentase hidup untuk masing-masing sumber anakan (bibit dan propagul) belum diketahui. Selain itu, rehabilitasi dengan penanaman langsung menggunakan propagul belum pernah dilakukan.

Penanaman $R$. stylosa di Desa Mendalok umumnya menggunakan pola tanam bujursangkar menggunakan bibit dengan jarak tanam $1 \mathrm{~m}$ x $1 \mathrm{~m}, 1 \mathrm{~m}$ x 2 $\mathrm{m}$ atau $1 \mathrm{~m} \times 3 \mathrm{~m}$. Belum pernah dilakukan penanaman dengan pola tanam cluster yang membuat jarak antar anakan mangrove rapat dan Rhizophora lebih kuat menghadapi arus laut. Oleh karena itu perlu dilakukan penelitiantentang tingkat keberhasilan pertumbuhan propagul dan bibit $R$. stylosa. pada tapak berlumpur dengan pola tanam bujursangkar $(1 \mathrm{~m} \times 1 \mathrm{~m})$ dan pola tanam cluster $(0,2 \mathrm{~m} \times 0,5 \mathrm{~m})$.

Penelitian ini bertujuan untuk menemukan sumber anakan dan pola tanam yang sesuai pada tapak berlumpur di areal rehabilitasi mangrove Desa Mendalok. Penelitian ini diharapkan dapat memberikan informasi tentang tingkat pertumbuhan propagul dan bibit $R$. stylosa pada tapak berlumpur dengan pola tanam bujursangkar dan pola tanam cluster. Informasi tersebut dapat digunakan sebagai dasar pertimbangan untuk menentukan kebijakan pada pelaksanaan rehabilitasi mangrove.

METODE PENELITIAN

\section{Waktu dan Lokasi Penelitian}

Penelitian dilakukan pada Areal Rehabilitasi Mangrove Desa Mendalok Kabupaten Mempawah. Waktu penelitian dilaksanakan pada bulan Juni - September 2017.

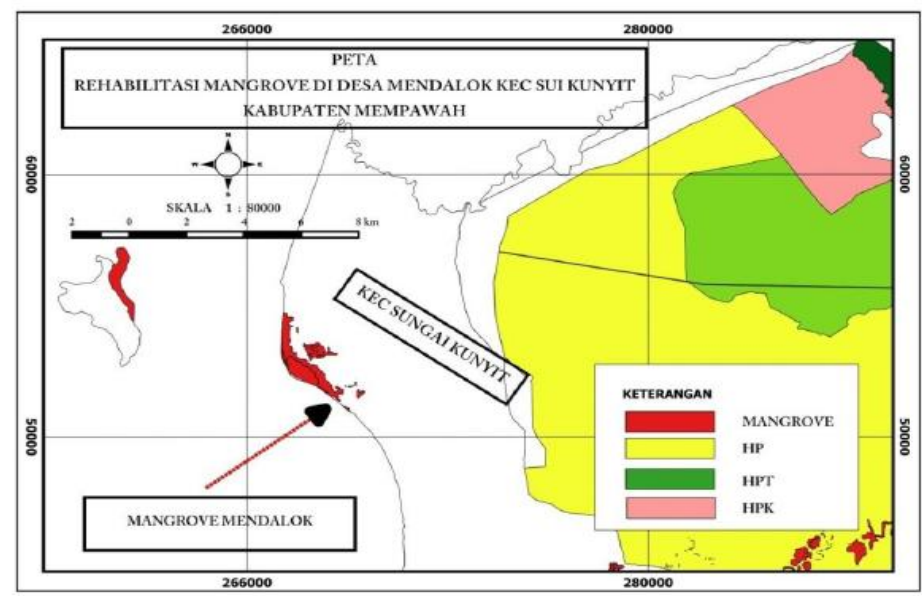

\section{Gambar 1. Peta Lokasi Penelitian di Desa Mendalok (The Map of Research Location in Mendalok Village)}

\section{Bahan dan Alat}

Bahan yang digunakan dalam penelitian ini adalah (1) Bibit/ semai $R$. stylosa. Bibit berdaun $4-6$ helai berasal dari persemaian. Benih/ propagul asal bibit diambil dari lokasi sekitar areal rehabilitasi mangrove Desa Mendalok. (2) Propagul $R$. stylosa umur 1 - 4 hari. Propagul diambil dari buah matang yang telah terlepas dari pohon induk di lokasi setempat. Sedangkan peralatan yang digunakan adalah (1) Bambu/ kayu ukuran 1 - 1,5 meter; (2) Tali rapiah; (3) Kaliper; (4) Penggaris; (5) Plastik untuk label 
penomoran tanaman; (6) Laptop untuk alat bantu pengolahan data; (7) Alat tulis dan tally sheet untuk pengambilan data; (8) Kamera; (9) Kantong plastik untuk tempat sampel tanah; (10) Baskom untuk alat bantu berjalan dilumpur.

\section{Prosedur Penelitian}

\section{Langkah Kerja}

Langkah kerja pada penelitian ini sebagai berikut:

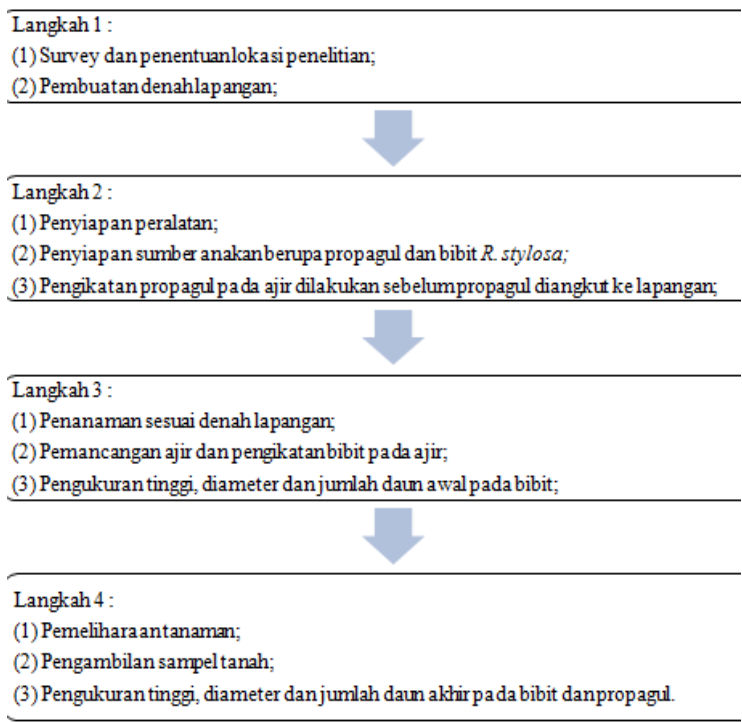

\section{Pengukuran dan Pengambilan Data}

Pengukuran parameter pertumbuhan bibit dan propagul $R$. stylosa meliputi Persen hidup (\%), Pertumbuhantinggi $(\mathrm{cm})$, Pertumbuhan diameter $(\mathrm{cm})$, Pertumbuhan jumlah daun (helai). Pengamatan ini dilakukan pada akhir pengamatan. Selain itu dilakukan analisis kandungan sifat fisik dan sifat kimia tanah.

\section{Rancangan Percobaan}

Penelitian ini menggunakan rancangan percobaan faktorial dengan rancangan dasar Rancangan Acak Lengkap (RAL). Faktor sumber anakan terdiri atas 2 taraf yaitu $\mathrm{A}_{1}$ (Bibit $R$. stylosa) dan $\mathrm{A}_{2}$ (Propagul $R$. stylosa). Faktor Pola Tanam terdiri atas 2 taraf yaitu
$\mathrm{B}_{1}$ (Pola Tanam bujur sangkar) dan $\mathrm{B}_{2}$ (Pola Tanam cluster). Penelitian ini merupakan percobaan faktorial 2 x 2 , sehingga terdapat 4 (empat) kombinasi perlakuan yaitu (1) $\mathrm{A}_{1} \mathrm{~B}_{1}$ merupakan Kombinasi perlakuan bibit $R$. stylosadengan penanaman pola bujursangkar; (2) $\mathrm{A}_{1} \mathrm{~B}_{2}$ merupakan Kombinasi perlakuan bibit $R$. stylosa dengan penanaman pola cluster; (3) $\mathrm{A}_{2} \mathrm{~B}_{1}$ merupakan Kombinasi perlakuan propagul $R$. stylosa dengan penanaman polabujursangkar; (4) $\mathrm{A}_{2} \mathrm{~B}_{2}$ : Kombinasi perlakuan propagul $R$. stylosa dengan penanaman pola cluster. Penelitian dilakukan dengan masing-masing perlakuan diulang sebanyak 5 kali.

Model statistik yang digunakan pada penelitian ini sebagai berikut :

$$
\mathbf{Y}_{\mathrm{ijk}}=\mathbf{u}+\boldsymbol{\alpha}_{\mathrm{i}}+\boldsymbol{\beta}_{\mathrm{j}}+(\boldsymbol{\alpha} \boldsymbol{\beta})_{\mathrm{ij}}+\varepsilon_{\mathrm{ijk}}
$$

di mana $\mathrm{Y}_{\mathrm{ijk}}$ merupakan nilai pengamatan pada satuan percobaan ke-k yang memperoleh kombinasi perlakuan ij; $\mathrm{u}$ adalah nilai tengah populasi (rata-rata sesungguhnya; $\alpha_{i}$ merupakan pengaruh aditif tarif ke-i dari faktor $\mathrm{A} ; \beta_{\mathrm{j}}$ merupakan pengaruh aditif tarif ke-j dari faktor $\mathrm{B}$; $(\alpha \beta)_{\mathrm{ij}}$ merupakan pengaruh interaksi tarif ke-i faktor A dan taraf ke-j dari faktor $\mathrm{B}$; dan $\varepsilon_{\mathrm{ijk}}$ adalah pengaruh galat dari satuan percobaan ke-k yang memperoleh kombinasi perlakuan ij (Gaspersz, 1991). Data yang dikumpulkan akan dianalisis dengan program SAS. Jika perlakuan menunjukkan pengaruh nyata dan sangat nyata maka dilakukan analisis lanjut dengan Uji jarak berganda Duncan

\section{Penanaman di Lapangan}

Pola tanam Propagul dan Bibit $R$. stylosa adalah (1) Pola Bujursangkar 
dengan luas blok $5 \mathrm{~m}$ x $6 \mathrm{~m}$ untuk 30 lubang tanam bibit atau propagul. Jarak antar tanaman adalah $1 \mathrm{~m} \times 1 \mathrm{~m}$; (2) Pola Cluster dengan luas blok $1 \mathrm{~m}$ x $3 \mathrm{~m}$ untuk 30 lubang tanam bibit atau propagul. Jarak

\section{A. POLA TANAM BUJURSANGKAR Jarak Tanam $1 \mathrm{~m} \times 1 \mathrm{~m}$ Luas Petak $5 \mathrm{mx} 6 \mathrm{~m}$}

$$
\begin{array}{|lllll|}
x & x & x & x & x \\
x & x & x & x & x \\
x & x & x & x & x \\
x & x & x & x & x \\
x & x & x & x & x \\
x & x & x & x & x
\end{array} \quad 6 m
$$

Penanaman anakan mangrove pada kondisi tapak berlumpur di areal mangrove dengan tipe kajapah ini harus mempunyai ajir yang menancap kuat. antar tanaman adalah $0,2 \mathrm{~m} \times 0,5 \mathrm{~m}$. Penanaman dilakukan dengan membuat 20 blok yang sejajar garis pantai. Denah penanaman diisi oleh kombinasi perlakuan secara acak lengkap.

\section{Jarak tanam $0,2 \mathrm{~m} \times 0,5 \mathrm{~m}$}

Luas Petak $1 \mathrm{~m} \times 3 \mathrm{~m}$

Tabel 1. Kebutuhan propagul dan bibit $R$. stylosa untuk setiap kombinasi perlakuan (The Need Propagules and Seeds of R. stylosa for Each Treatment Combination)

\begin{tabular}{lcl}
\hline Kombinasi perlakuan & Jumlah (btg) & Keterangan \\
\hline $\mathrm{A}_{1} \mathrm{~B}_{1}$ & 150 & 1 bibit ditanam pada 1 lubang tanam \\
$\mathrm{A}_{1} \mathrm{~B}_{2}$ & 150 & 1 bibit ditanam pada 1 lubang tanam \\
$\mathrm{A}_{2} \mathrm{~B}_{1}$ & 300 & 2 propagul ditanam pada 1 lubang tanam \\
$\mathrm{A}_{2} \mathrm{~B}_{2}$ & 300 & 2 propagul ditanam pada 1 lubang tanam \\
\hline \\
Pada penanaman bibit dilakukan & penanaman sebagai berikut (1) \\
teknik penanaman sebagai berikut (1) & Penyiapan ajir berupa kayu kecil \\
Bibit ditanam sesuai dengan denah & dengan panjang 100-120 cm; (2) \\
lapangan yang telah ditentukan; (2) Ajir & Propagul diikat pada ajir dengan \\
dari bambu ditancapkan disamping bibit & menggunakan tali rapiah. \\
dengan kedalaman \pm 70 -100 cm; (3) & Penelitian ini menggunakan 2 buah \\
Bibit diikat pada ajir dengan & propagul yang diikat kuat pada sebatang \\
menggunakan tali rapiah. Penanaman & ajir. Penggunaan 2 buah propagul \\
propagul dilakukan melaluiteknik & karena pada awal pertumbuhan sangat
\end{tabular}


rentan terhadap serangan hama. Penghitungan data propagul diambil 1 data dari setiap lubang tanam; (3) Cara pengikatan kayu pada propagul dilakukan dengan mengikat $1 / 3$ bagian bawah propagul pada $1 / 4$ bagian atas ajir. Pengikatan harus kuat agar propagul tidak terlepas ketika arus dan gelombang kuat. Langkah ini dapat dilakukan dirumah; (4) Pada saat dilapangan kayu yang sudah terikat propagul tersebut langsung ditanam sesuai dengan denah lapangan. Penanaman dilakukan dengan membenamkan kayu tersebut sampai dengan maksimal 1/3 bagian bawah propagul. (5) Pada tahap awal pertumbuhan yaitu pada 1 sampai 2 bulan pertama, perlu dilakukan monitoring penanaman. Saat propagul terlalu dalam terendam lumpur, perlu dilakukan penarikan kayu penyanggah agar posisi propagul tetap stabil bagi pertumbuhannya.

\section{HASIL DAN PEMBAHASAN}

\section{Persen Hidup Rhizophora stylosa}

Penentuan persen hidup bibit dan propagul dilakukan setelah 4 bulan penanaman. Penghitungan persen hidup dilakukan melalui pengamatan terhadap jumlah tanaman yang hidup pada setiap petaknya. Hasil penelitian menunjukkan bahwa faktor perlakuan Sumber Anakan (A) berpengaruh sangat nyata, sedangkan Perlakuan Pola Tanam (B) dan interaksi faktor Sumber Anakan dan Pola Tanam (AB) tidak berpengaruh (Tabel 2).

Tabel 2. Sidik ragam persen hidup propagul dan bibit $R$. stylosa umur 4 bulan dengan pola tanam bujursangkar dan cluster (examination style of life percentage of propagules and seeds $R$. stylosa age 4month with square plant patterns and cluster)

\begin{tabular}{ccrrll}
\hline $\begin{array}{c}\text { Sumber } \\
\text { Keragaman }\end{array}$ & DB & JK & KT & Fhit & Pr $>$ F \\
\hline Perlakuan & 3 & 414,950 & 138,317 & $3,640 *$ & 0,036 \\
A & 1 & 378,450 & 378,450 & $9,959 * *$ & 0,006 \\
B & 1 & 22,050 & 22,050 & 0,580 & 0,457 \\
AB & 1 & 14,450 & 14,450 & 0.380 & 0,546 \\
Galat & 16 & 608,000 & 38,000 & &
\end{tabular}

\begin{tabular}{cccc}
\hline Total & 19 & 1022,950 & \\
\hline $\mathrm{CV}=42,37$ & & $*$ nyata $\quad * *=$ sangat nyata
\end{tabular}

Berdasarkan Uji Lanjut Duncan bahwa perlakuan $\mathrm{A}_{1} \mathrm{~B}_{1}$ (Bibit dengan pola tanam bujursangkar) berbeda nyata terhadap $\mathrm{A}_{2} \mathrm{~B}_{1}$ (Propagul dengan pola tanam bujursangkar). Perlakuan $\mathrm{A}_{1} \mathrm{~B}_{1}$ tidak berbeda nyata terhadap $\mathrm{A}_{1} \mathrm{~B}_{2}$ (Bibit dengan pola tanam cluster) dan perlakuan $\mathrm{A}_{2} \mathrm{~B}_{2}$ (Propagul dengan pola tanam cluster) pada taraf $5 \%$ (Gambar 2). 


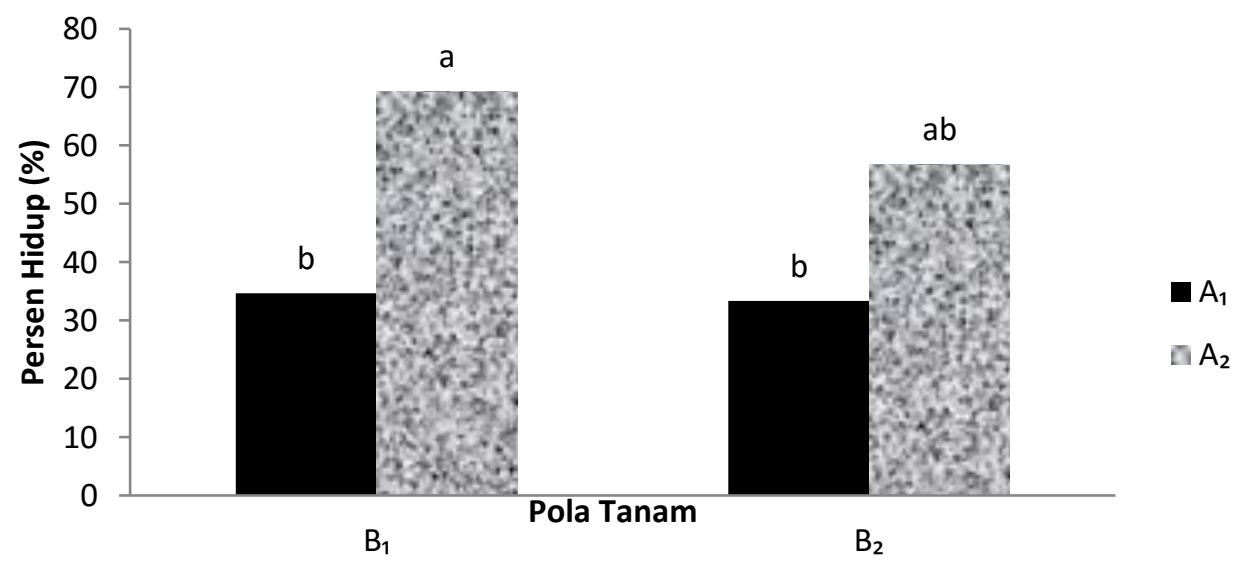

Gambar 2. Persen Hidup $R$. stylosa umur 4 bulan pada tapak berlumpur di Desa Mendalok (Percent Life $R$. stylosa age 4 months on muddy site in Mendalok Village)

Persentase hidup yang lebih tinggi pada propagul dengan pola tanam bujursangkar $\left(\mathrm{A}_{2} \mathrm{~B}_{1}\right)$ karena beberapa faktor antara lain pertama Propagul akan langsung membentuk akar ketika menemukan tempat hidup yang sesuai, pertumbuhan ini ditunjang dari ketersediaan cadangan makanan dari propagul itu sendiri, sedangkan pada pertumbuhan bibit diperlukan masa adaptasi terhadap lingkungan saat awal penanaman di lapangan; kedua Pengikatan propagul dengan kayu ajir yang difungsikan sebagai tongkat penyanggah bagian bawah. Penyanggah akan memperkuat propagul menghadapi arus dan gelombang pasang surut; Ketiga Penanaman dilakukan menggunakan 2 (dua) buah propagul pada setiap lubang tanam; Keempat Pada pola tanam bujursangkar (jarak tanam $1 \mathrm{~m} \mathrm{x} 1 \mathrm{~m}$ ), tanaman yang mati akibat kuatnya hempasan ombak pasang surut relatif lebih sedikit dibandingkan pola tanam cluster. 


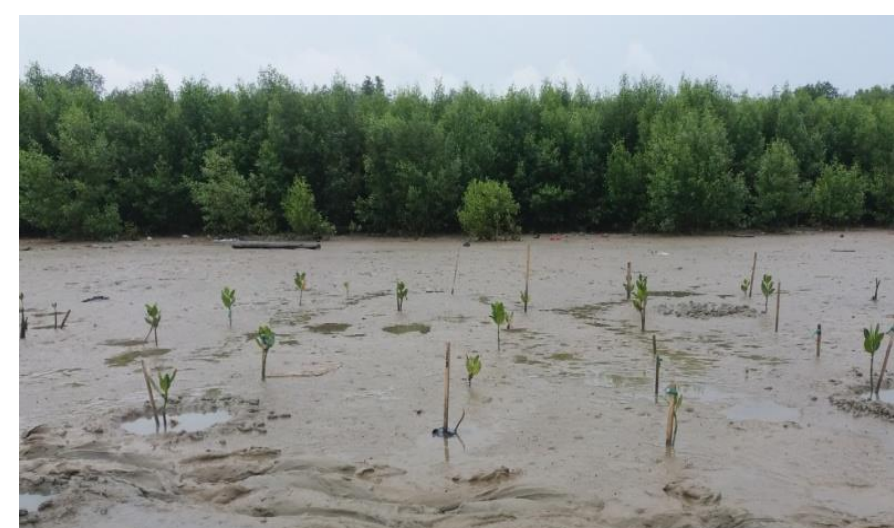

a. Bibit $R$. stylosa dengan pola tanam bujursangkar (Seeds R.stylosa with square plant pattern)

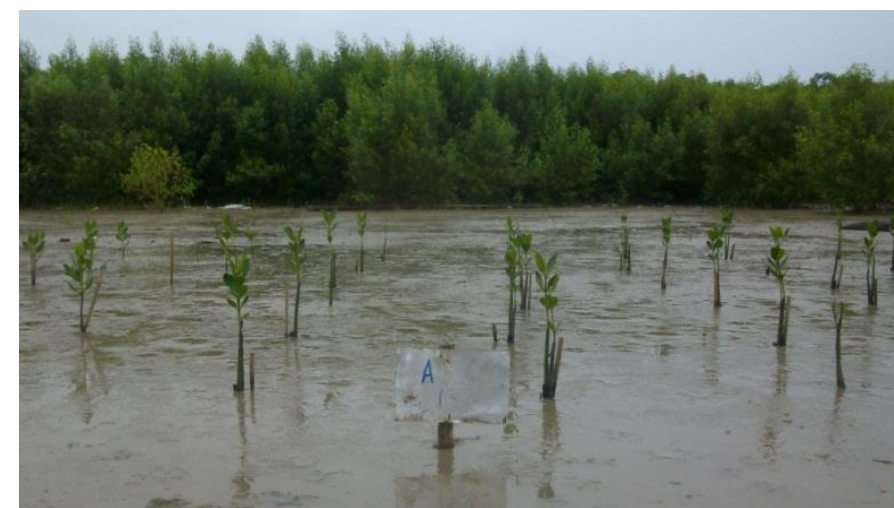

c. Propagul $R$. stylosa dengan pola tanam bujursangkar (Propagule R. stylosa with square plant patterns)

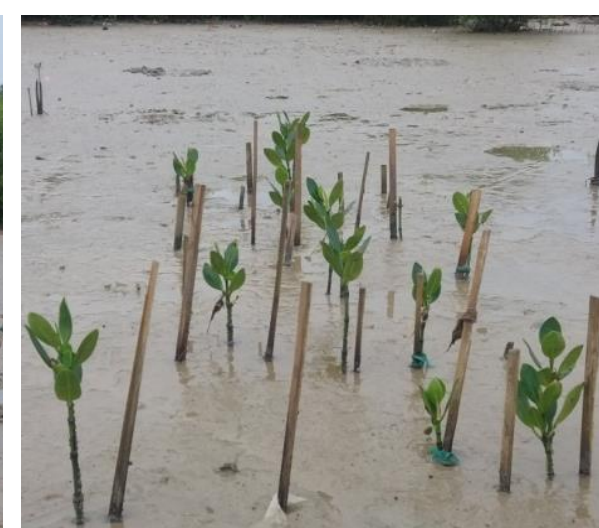

b. Bibit $R$. stylosa dengan pola tanam cluster (Seeds R.stylosa with cluster plant patterns)

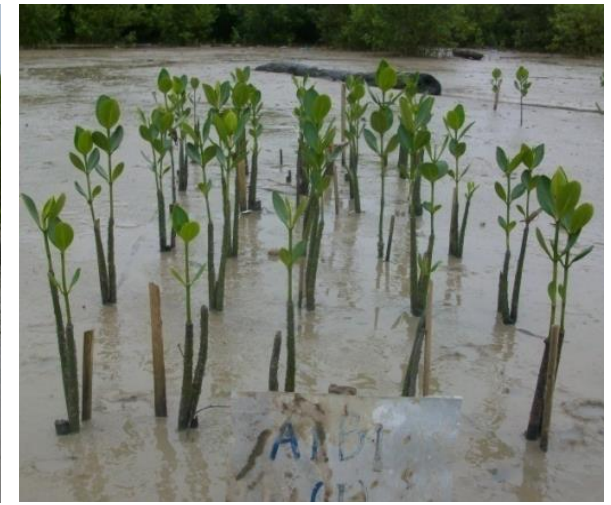

$d$. Propagul $R$. stylosa dengan pola tanam cluster(Propagule R. stylosa with cluster plant patterns)

Gambar 3. Pertumbuhan Propagul dan Bibit R. stylosa umur 4 bulan Pada Setiap Kombinasi Perlakuan (Propagul and R. stylosa 4 month Age of Propagulant Growth on Each Combination Treatment)

Penanaman dengan pola bujursangkar pada bibit atau propagul menunjukkan persen hidup yang lebih tinggi dibandingkan pola tanam cluster. Ketika arus kuat menghantam petak tanam bibit atau propagul dengan pola tanam bujursangkar, maka jumlah yang terdampak relatif lebih sedikit dibandingkan petak dengan pola tanam cluster. Bibit atau propagul yang ditanam pada petak dengan pola tanam cluster akan terdampak arus dan gelombang kuat secara bersamaan. Hal ini sesuai penelitian Halidah (2009), penanaman $R$. Mucronata menunjukkan persen hidup lebih tinggi pada jarak tanam 2 x 1,5 yaitu sebesar 98,88\% Jarak tanam yang lebih rapat menunjukkan persen hidup lebih rendah, yaitu sebesar 75,55 \% untuk jarak tanam 1x2 m, 78,88 \% untuk jarak tanam $1 \times 1 \mathrm{~m}$ dan 70,22\% untuk jarak tanam $0,5 \times 0,5 \mathrm{~m}$. 


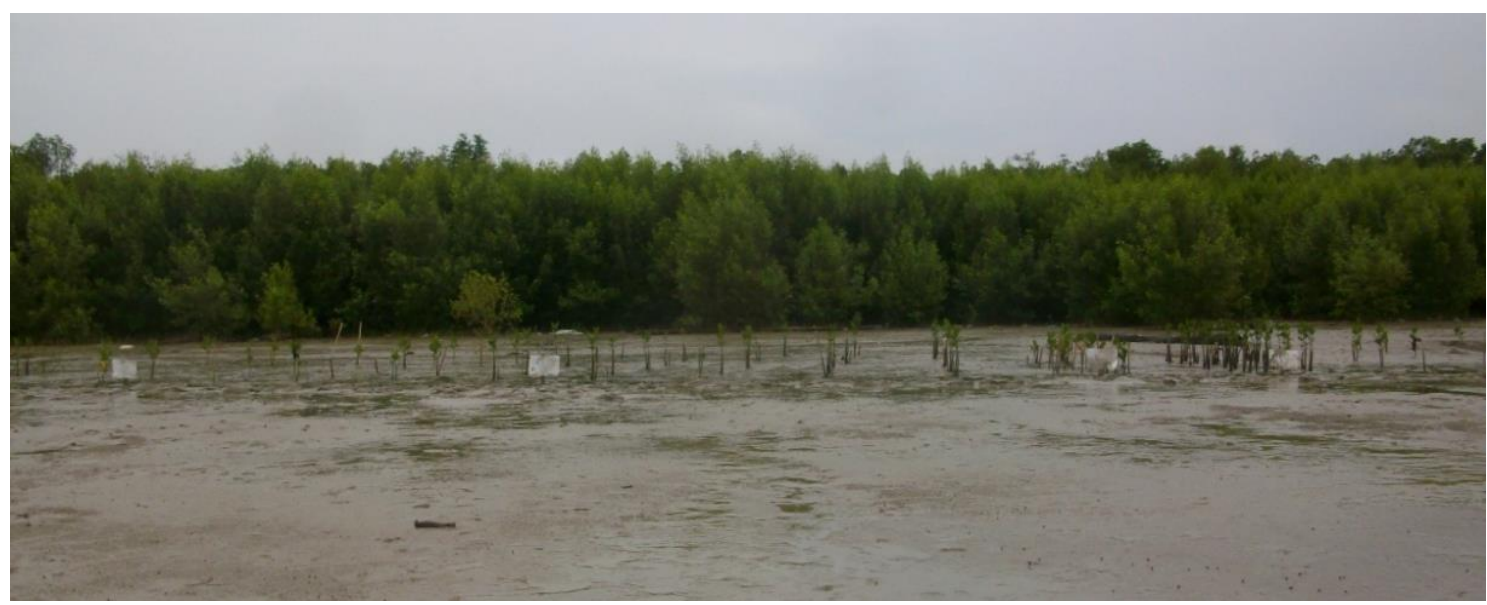

Gambar 4. Kondisi lokasi penelitian setelah 4 bulan penanaman (Condition of study location after 4 months of planting)

Berdasarkan pengamatan pada penanaman propagul dan bibit dengan pola tanam cluster sangat perlu dilakukan pengendalian terhadap sampah dari laut. Hal ini dapat dilakukan dengan selalu memantau lokasi penanaman terutama setelah air laut pasang besar. Sampah plastik cenderung lebih mudah tersangkut pada pola tanam cluster sehingga dapat mengganggu pertumbuhan. Selain itu, penanaman dengan propagul, terdapat kecenderungan serangan hama yang menyerang tunas muda sehingga gagal pada pertumbuhannya. Propagul dengan jarak tanam yang dekat (cluster) menyebabkan propagul rentan terhadap serangan hama secara bersamaan. Hama yang banyak terdapat di sekitar lokasi penanaman seperti keramak (Ucasp).

\section{Pertumbuhan Tinggi Propagul dan Bibit Rhizophora stylosa}

Pertumbuhan tinggi ditentukan dengan pengukuran setelah 4 bulan penanaman. Pertumbuhan tinggi pada bibit ditentukan dengan menghitung selisih tinggi akhir dikurangi tinggi awal, sedangkan pada propagul pertumbuhan tinggi dihitung berdasarkan hasil pengukuran tinggi mulai dari pangkal batang sampai titik tumbuh tanaman. Hasil penelitian menunjukkan bahwa faktor perlakuan memberikan pengaruh sangat nyata. Perlakuan A (Sumber anakan) memberikan pengaruh yang sangat nyata, sedangkan Perlakuan B (Pola tanam) dan interaksi faktor $\mathrm{AB}$ tidak berpengaruh nyata terhadap pertumbuhan tinggi bibit dan propagul (Tabel 3). 
Tabel 3. Sidik ragam pertumbuhan tinggi propagul dan bibit $R$. stylosa umur 4 bulan dengan pola tanam bujursangkar dan cluster (Examination style of High growth Propagules and Seeds $R$. stylosa age 4 month with cropping pattern of rectangular and cluster)

\begin{tabular}{ccrrrl}
\hline $\begin{array}{c}\text { Sumber } \\
\text { Keragaman }\end{array}$ & DB & \multicolumn{1}{c}{ JK } & \multicolumn{1}{c}{ KT } & F $_{\text {hit }}$ & Pr $>$ F \\
\hline Perlakuan & 3 & 47,191 & 15,730 & $28,919^{* *}$ & 0,000 \\
A & 1 & 47,186 & 47,186 & $86,746^{* *}$ & 0,000 \\
B & 1 & 0,000 & 0,000 & 0,001 & 0,981 \\
AB & 1 & 0,005 & 0,005 & 0,009 & 0,924 \\
Galat & 16 & 8,703 & 0,544 & & \\
\hline Total & 19 & 55,895 & & ** = sangat nyata
\end{tabular}

Hasil Uji Lanjut Duncan menunjukkan bahwa perlakuan $\mathrm{A}_{1} \mathrm{~B}_{1}$ (Bibit dengan pola tanam bujursangkar) berbeda nyata terhadap $\mathrm{A}_{2} \mathrm{~B}_{1}$ (Propagul dengan pola tanam bujursangkar) dan

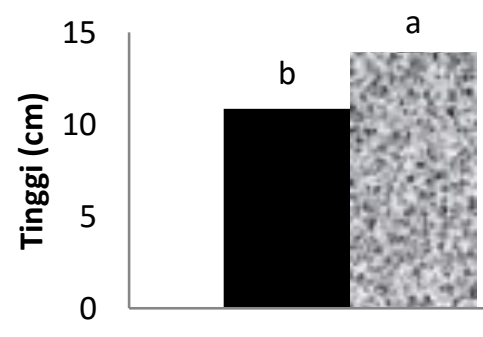

$B_{1}$ perlakuan $\mathrm{A}_{2} \mathrm{~B}_{2}$ (Propagul dengan pola tanam cluster). Perlakuan $\mathrm{A}_{1} \mathrm{~B}_{1}$ tidak berbeda nyata terhadap $\mathrm{A}_{1} \mathrm{~B}_{2}$ (Bibit dengan pola tanam cluster) pada taraf 5 $\%$ (Gambar 5).

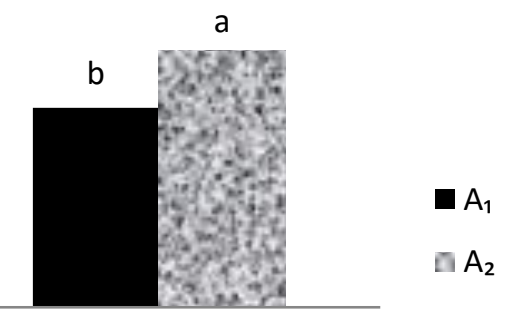

$\mathrm{B}_{2}$

Pola Tanam

Gambar 5. Rerata pertumbuhan tinggi propagul dan bibit $R$. stylosa umur 4 bulan dengan pola tanam bujursangkar dan cluster (The high growth rate of propagul and $R$. stylosa seedlings of 4 months age with square plant patterns and cluster)

Pertumbuhan tinggi pada propagul lebih baik dapat disebabkan karena ketersediaan unsur-unsur hara bagi pertumbuhannya terpenuhi dari buah/ propagul itu sendiri. Tomlinson (1986) dalam Basyuni et al (2014) menyebutkan bahwa $R$. stylosa merupakan mangrove dengan buah vivivar yang mampu mendapatkan unsur-unsur bagi pertumbuhannya dari tanah atau dari propagul itu sendiri. Hutahaean et al (1999) menyebutkan umumnya respon pertumbuhan tinggi yang baik diperoleh pada salinitas yang rendah, hal ini karena mangrove merupakan tumbuhan yang toleran terhadap garam (salt tolerance) bukan tumbuhan yang membutuhkan garam (salt demand). Penelitian Basyuni et al (2014) menyatakan pertumbuhan tinggi $R$. stylosa terbaik pada salinitas $0,00 \%$ sebesar $19,58 \mathrm{~cm}$ dan pertumbuhan diameter terbaik pada salinitas 0,5\% yaitu sebesar 4,7 mm. Menurut 
Hutahaean et al (1999), jenis Rhizophora mucronata memiliki pertumbuhan tinggi paling baik pada salinitas 7,50 - 15,0 ppt dan $0,0-7,5$ ppt.

\section{Pertumbuhan Diameter Propagul dan Bibit $R$. stylosa}

Pertumbuhan diameter ditentukan berdasarkan hasil pengukuran setelah 4 bulan penanaman. Pengukuran diameter dilakukan pada titik tertentu di atas pangkal batang mengunakan kaliper dalam satuan $\mathrm{cm}$. Pertumbuhan diameter bibit ditentukan dengan menghitung selisih diameter akhir dikurangi diameter awal, sedangkan diameter propagul dihitung berdasarkan hasil pengukuran setelah 4 bulan penanaman. Perlakuan A (Sumber anakan) memberikan pengaruh sangat nyata, sedangkan Perlakuan B (Pola tanam) dan interaksi faktor $\mathrm{AB}$ tidak berpengaruh terhadap pertumbuhan diameter bibit dan propagul $R$. stylosa (Tabel 4).

Tabel 4. Sidik ragam pertumbuhan diameter propagul dan bibit $R$. stylosa umur 4 bulan dengan pola tanam bujursangkar dan cluster (Examination style of Fertilization pattern of propagule diameter and $R$. stylosa 4 month age seedlings with square plant patterns and cluster)

\begin{tabular}{ccrrrr}
\hline $\begin{array}{c}\text { Sumber } \\
\text { Keragaman }\end{array}$ & DB & \multicolumn{1}{c}{ JK } & \multicolumn{1}{c}{ KT } & \multicolumn{1}{c}{ F $_{\text {hit }}$} & Pr $>$ F \\
\hline Perlakuan & 3 & 0,039 & 0,013 & $31,934^{* *}$ & 0,000 \\
A & 1 & 0,039 & 0,039 & $95,605^{* *}$ & 0,000 \\
B & 1 & $8,000 \mathrm{E}-5$ & $8,000 \mathrm{E}-5$ & 0,198 & 0,663 \\
AB & 1 & 0,000 & 0,000 & 0,000 & 1,000 \\
Galat & 16 & 0,006 & 0,000 & & \\
\hline Total & 19 & 0,045 & & & \\
\hline CV $=4,06$ & & & & & \\
& & & &
\end{tabular}

Hasil Uji Lanjut Duncan menunjukkan perlakuan $\mathrm{A}_{1} \mathrm{~B}_{1}$ (Bibit dengan pola tanam bujursangkar) berbeda nyata terhadap $\mathrm{A}_{2} \mathrm{~B}_{1}$ (Propagul dengan pola tanam bujursangkar) dan perlakuan $\mathrm{A}_{2} \mathrm{~B}_{2}$ (Propagul dengan pola tanam cluster). Perlakuan $\mathrm{A}_{1} \mathrm{~B}_{1}$ tidak berbeda nyata terhadap $\mathrm{A}_{1} \mathrm{~B}_{2}$ (Bibit dengan pola tanam cluster) pada taraf 5 $\%$ (Gambar 6).

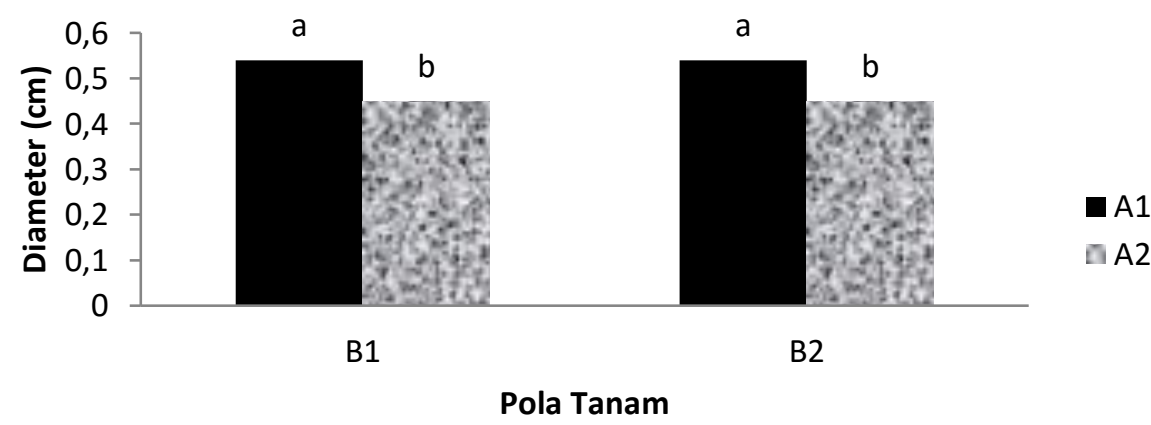

Gambar 6. Rerata pertumbuhan diameter propagul dan bibit $R$. stylosa umur 4 bulan dengan pola tanam bujursangkar dan cluster (Mean growth rate of propagule diameter and $R$. stylosa seedlings age 4 monthswith square plant patterns and cluster) 
Pertumbuhan diameter pada bibit lebih baik dibandingkan propagul. Di dalam kurun waktu 7 (tujuh) bulan pengamatan sejak di persemaian umur bibit secara keseluruhan lebih tinggi dibandingkan umur propagul yaitu 4 (empat) bulan. Hal ini sejalan dengan penelitian Syah (2011), yang menyatakan bahwa umur tanaman mempengaruhi pertambahan diameter, dimana semakin meningkat umur tanaman maka semakin meningkat pula pertambahan diameternya.

Bibit yang mampu beradaptasi dengan lingkunganakanterus melakukan metabolisme di dalam tubuhnya. Bibit akan terus tumbuh dengan perkembangan kambium dan perkembangan sel-sel jaringan meristem. Perkembangan kambium dan sel-sel jaringan meristem ini menunjukkan pertumbuhan diameter atau pertumbuhan lingkaran tahun (Baker, 1950 dalam Syah, 2011).

\section{Pertumbuhan Jumlah Daun Propagul dan Bibit $R$. stylosa}

Jumlah daun ditentukan dengan penghitungan setelah 4 bulan penanaman. Jumlah daun pada bibit ditentukan dengan menghitung selisih jumlah daun akhir (dihitung berdasarkan bekas tempat tumbuhnya daun) dikurangi jumlah daun awal, termasuk jumlah daun yang ada pada cabang tanaman. Jumlah daun propagul dihitung mulai dari daun pertama sampai daun yang ada pada titik tumbuh. Penelitian menunjukkan bahwa faktor perlakuan memberikan pengaruh yang sangat nyata. Perlakuan A (Sumber anakan) memberikan pengaruh yang sangat nyata, sedangkan Perlakuan B (Pola tanam) dan interaksi faktor $A B$ tidak berpengaruh terhadap pertumbuhan jumlah daun bibit dan propagul R. stylosa (Tabel 5).

Tabel 5. Hasil Sidik ragam pertumbuhan jumlah daun propagul dan bibit $\boldsymbol{R}$. stylosa umur 4 bulan dengan pola tanam bujursangkar dan cluster (Examination style of growth of propagule leaves and seedlings $R$. stylosa age 4 months with square plant patterns and cluster)

\begin{tabular}{|c|c|c|c|c|c|}
\hline $\begin{array}{c}\text { Sumber } \\
\text { Keragaman }\end{array}$ & DB & JK & KT & $\mathbf{F}_{\text {hit }}$ & $\operatorname{Pr}>\mathbf{F}$ \\
\hline Perlakuan & 3 & $38,574^{\mathrm{a}}$ & 12,858 & $16,966 * *$ & 0,000 \\
\hline A & 1 & 38,420 & 38,420 & $50,696 * *$ & 0,000 \\
\hline $\mathrm{B}$ & 1 & 0,029 & 0,029 & 0,038 & 0,848 \\
\hline $\mathrm{AB}$ & 1 & 0,125 & 0,125 & 0,165 & 0,690 \\
\hline Galat & 16 & 12,125 & 0,758 & & \\
\hline Total & 19 & 50,699 & & & \\
\hline \multirow{2}{*}{\multicolumn{3}{|c|}{$\begin{array}{l}\text { Uji Lanjut Duncan menunjukkan } \\
\text { bahwa perlakuan } \mathrm{A}_{1} \mathrm{~B}_{1} \text { (Bibit dengan } \\
\text { pola tanam bujursangkar) berbeda nyata } \\
\text { terhadap } \mathrm{A}_{2} \mathrm{~B}_{1} \text { (Propagul dengan pola } \\
\text { tanam bujursangkar) dan perlakuan }\end{array}$}} & \multicolumn{3}{|c|}{$* *=$ sangat nyata } \\
\hline & & & \multicolumn{3}{|c|}{$\begin{array}{l}\mathrm{A}_{2} \mathrm{~B}_{2} \text { (Propagul dengan pola tanam } \\
\text { cluster). Perlakuan } \mathrm{A}_{1} \mathrm{~B}_{1} \text { tidak berbeda } \\
\text { nyata terhadap } \mathrm{A}_{1} \mathrm{~B}_{2}(\mathrm{Bibit} \text { dengan pola } \\
\text { tanam cluster) pada taraf } 5 \% \text { (Gambar } \\
7 \text { ). }\end{array}$} \\
\hline
\end{tabular}


Gambar 7. Rerata pertumbuhan jumlah daun propagul dan bibit $R$. stylosa umur 4 bulan dengan pola tanam bujursangkar dan cluster (Mean of growth of propagule leaf and R.stylosa seedlings 4 month age with square plant patterns and cluster)

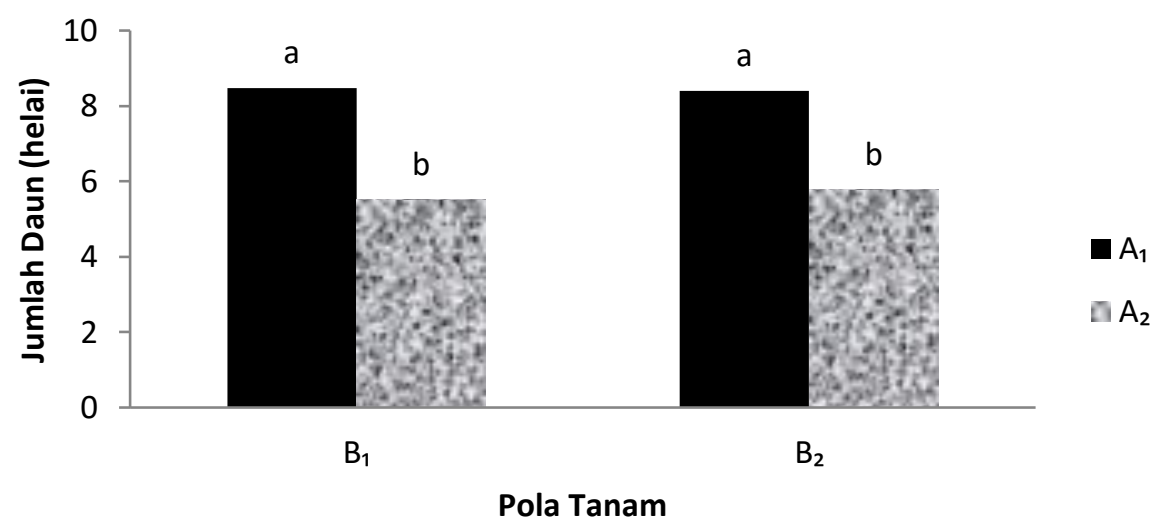

Pertumbuhan jumlah daun pada bibit lebih baik dibandingkan propagul. Hal ini terjadi karena umur bibit lebih tua dibandingkan umur propagul. Bibit dengan daun awal 4-6 helai merupakan bibit dengan umur sekitar 3 bulan di persemaian. Setelah berakhir penelitian umur tanaman yang berasal dari bibit sekitar 7 (tujuh) bulan. Memasuki bulan ke-4 (empat) penanaman, beberapa bibit mulai mengeluarkan cabang dari ketiak daunnya dan pada cabang tersebut akan muncul daun baru. Bibit $R$. stylosa yang ditanam akan menggugurkan daun daun tuanya. Daun-daun tua akan berwarna kuning dan akhirnya lepas. Lepasnya daun tua pada $R$. stylosa merupakan cara adaptasinya terhadap lingkungan yang salin. $R$. stylosa merupakan mangrove non secreter yaitu jenis mangrove yang tidak mempunyai struktur kelenjar garam. Kelompok mangrove non secreter mekanisme pengeluaran garam terjadi ketika daun atau bagian tumbuhan lainnya terlepas
(Onrizal, 2005). R. stylosa mampu untuk mengeluarkan garam yang berlebih melalui akar ultrafiltrasi, namun tidak memiliki kemampuan untuk mengeluarkan garam melalui daun (Tomlinson, 1986 dalam Basyuni et al, 2014). Daun tua umumnya akan gugur dan ini merupakan salah satu mekanisme pelepasan garam dari tanaman.

\section{Identifikasi Tempat Tumbuh}

Tanah sebagai substrat bagi pertumbuhan mangrove dapat dikategorikan berdasarkan kematangannya. Tanah yang stabil atau keras merupakan tanah yang sudah matang, sedangkan tanah yang lunak atau lembek merupakan ciri tanah yang belum matang. Tanah ini biasanya disebut tanah berlumpur. $R$. stylosa merupakan salah satu jenis yang cocok hidup pada substrat lumpur berpasir, berbatu atau berkoral dan kearah laut (Kusmana et al, 2008 dan Kusmana et al, 2014). 
Tabel 6. Hasil analisis sifat fisik dan sifat kimia tanah pada lokasi penelitian Desa Mendalok Kabupaten Mempawah (Result of analysis of physical properties and chemical properties of soil at research location Mendalok Village Mempawah District)

\begin{tabular}{|c|c|c|c|}
\hline Parameter analisis & Satuan & Nilai & Kriteria* \\
\hline $\mathrm{pH} \mathrm{H} \mathrm{H}_{2} \mathrm{O}$ & - & 7.58 & Netral \\
\hline $\mathrm{pH} \mathrm{KCl}$ & - & 7.32 & Netral \\
\hline C-Organik & $\%$ & 0.63 & Sangat Rendah \\
\hline Nitrogen Total & $\%$ & 0.09 & Sangat Rendah \\
\hline \multicolumn{4}{|l|}{ Ekstraksi Bray I } \\
\hline $\mathrm{P}_{2} \mathrm{O}_{5}$ & ppm & 34.73 & Tinggi \\
\hline \multicolumn{4}{|c|}{ Ekstraksi NH4OAC1N pH:7 } \\
\hline Kalsium & $\mathrm{cmol}(+) / \mathrm{kg}$ & 16.77 & Tinggi \\
\hline Magnesium & $\mathrm{cmol}(+) / \mathrm{kg}$ & 3.56 & Tinggi \\
\hline Kalium & $\mathrm{cmol}(+) / \mathrm{kg}$ & 1.04 & Sangat Tinggi \\
\hline Natrium & $\mathrm{cmol}(+) / \mathrm{kg}$ & 1.77 & Sangat Tinggi \\
\hline KTK & $\mathrm{cmol}(+) / \mathrm{kg}$ & 23.25 & Sedang \\
\hline Kejenuhan Basa & $\%$ & 99.53 & Sangat Tinggi \\
\hline \multicolumn{4}{|l|}{ Ekstraksi KCl 1 N } \\
\hline Alumunium & $\mathrm{cmol}(+) / \mathrm{kg}$ & 0.00 & \\
\hline Hidrogen & $\mathrm{cmol}(+) / \mathrm{kg}$ & 0.30 & \\
\hline \multicolumn{4}{|l|}{ Tekstur } \\
\hline Pasir & $\%$ & 1.54 & \\
\hline Debu & $\%$ & 60.44 & \\
\hline Liat & $\%$ & 38.02 & \\
\hline Salinitas & $\mathrm{ppt}$ & 7.33 & \\
\hline
\end{tabular}

Sumber : Hasil analisis tanah laboratorim tanah Fakultas Pertanian (2017)

*Kriteria berdasarkan LPT (1983)

Tanah pada lokasi penelitian merupakan substrat berlumpur dengan tekstur debu 60,44\%, liat 38,02\% dan pasir 1,54\% (Tabel 6). Propagul dan bibit $R$. stylosa dapat tumbuh pada lokasi ini dengan persen hidup bibit 34 $\%$ dan propagul $63 \%$. Tanah lempung dan debu merupakan tanah yang bertekstur halus dan memiliki kemampuan tinggi sebagai penyaring, namun memiliki permeabilitas rendah. Tanah dengan tekstur lempung dan debu mempunyai kapasitas penyangga cukup tinggi serta memiliki kandungan bahan organik tinggi (Sutanto, 2005).
Tanah di lokasi penelitian mempunyai $\mathrm{pH}$ 7,58 termasuk kriteria netral. $\mathrm{pH}$ tanah berpengaruh cukup besar terhadap ketersediaan unsur hara dalam tanah. Kondisi $\mathrm{pH} 5,0-7,5$ merupakan kondisi terbaik karena tidak mengandung bahan yang bersifat racun. Vegetasi mangrove dapat tumbuh optimal pada $\mathrm{pH}$ ini. Kandungan ion $\mathrm{Ca}$ $16,77 \mathrm{cmol} / \mathrm{kg}$ yang termasuk kriteria tinggi dan kandungan $\mathrm{Al}$ rendah yaitu 0,00 . Hal ini sesuai dengan Sutanto (2005), pada $\mathrm{pH}>7$ mempunyai konsentrasi ion $\mathrm{Ca}$ tinggi dan $\mathrm{pH}<5$ mengandung konsentrasi ion $\mathrm{Al}$ yang 
tinggi. Keasaman atau $\mathrm{pH}$ tanah yang netral karena banyaknya ion $\mathrm{Ca}, \mathrm{Mg}, \mathrm{K}$ dan Na. Onrizal (2005) menyebutkan bahwa ion-ion anorganik yang diambil oleh tanaman, seperti ion Natrium dan Clorida dimanfaatkan untuk proses fisiologi. Ion Natrium digunakan pada proses fotosintesis dan pertukaran kation, sedangkan ion Clorida untuk pengendalian tekanan osmosis dan proses fotosintesis.

Tanah dengan substrat lumpur merupakan tanah yang jenuh air, sehingga kandungan oksigen sangat terbatas. Kekurangan oksigen pada tanah diatasi dengan keberadaan satwa tanah seperti keramak (uca sp) dan tembakul (Periopthalmus sp) yang membuat lubang saat air laut surut dan kondisi tanah tidak tergenang. Akar tumbuhan mangrove mendapatkan oksigen melalui lubang-lubang ini sehingga respirasi tetap berjalan baik. Selain itu kondisi jenuh air pada tanah di toleransi oleh beberapa jenis mangrove dengan membuat perakaran khusus, ketersediaan oksigen untuk pertumbuhan jenis $R$. stylosa didukung dengan terbentuknya akar tunjang (Onrizal, 2005).

\section{KESIMPULAN}

Berdasarkan hasil analisis data penelitian, dapat disimpulkan sebagai berikut :

1. Persen hidup Rhizophora stylosa pada tapak berlumpur di Desa Mendalok pada umur 4 bulan dipengaruhi oleh sumber anakan sedangkan pola tanam tidak mempengaruhi persen hidup.
2. Persen hidup terbaik yaitu $69,33 \%$ ditunjukkan oleh kombinasi perlakuan sumber anakan yang berasal dari propagul dengan pola tanam bujursangkar $\left(\mathrm{A}_{2} \mathrm{~B}_{1}\right)$.

3. Perlakuan sumber anakan berpengaruh sangat nyata pada pertumbuhan tinggi, diameter dan jumlah daun $R$. stylosa. Propagul menunjukkan pertumbuhan tinggi lebih baik dibandingkan bibit. Bibit menunjukkan pertumbuhan diameter dan pertumbuhan jumlah daun lebih baik dibandingkan propagul.

4. Perlakuan pola tanam bujursangkar dan pola tanam cluster belum menunjukkan perbedaan nyata terhadap persen hidup, pertumbuhan tinggi, pertumbuhan diameter dan pertumbuhan jumlah daun pada propagul dan bibit R.stylosa sampai umur 4 bulan penanaman.

\section{SARAN}

Berdasarkan hasil penelitian ini, dapat disarankan sebagai berikut:

1. Penanaman $R$. stylosa untuk kegiatan rehabilitasi mangrove pada tapak berlumpur yang berhadapan langsung dengan laut dapat dilakukan dengan menggunakan propagul dan pola tanam bujursangkar (1 $\mathrm{m} \mathrm{x} 1 \mathrm{~m}$ ).

2. Penanaman propagul dapat dilakukan dengan teknik menggunakan kayu penyanggah yang diikatkan pada bagian bawah propagul.

3. Penanaman propagul dapat dilakukan dengan menggunakan 2 
(dua) hingga 5 (lima) propagul yang diikat pada sebatang kayu penyanggah.

4. Perlu dilakukan penelitian dengan waktu lebih dari 4 bulan untuk melihat pengaruh pola tanam terhadap pertumbuhan propagul dan bibit $R$. stylosa.

5. Perlu dilakukan penelitian tentang hama yang menyerang bibit dan propagul pada kondisi tapak berlumpur.

\section{DAFTAR PUSTAKA}

Basyuni M, Putri LAP, Nainggolan B, Sihaloho PE. 2014. Growth and Biomass in Response to Salinity and Subsequent Fresh Water in Mangrove Seedlings Avicennia and Rhizophora stylosa.Scientific Article. 1: 17-25.

Biro Humas Kementerian LHK. 2017. Miliki 23\% Ekosistem Mangrove Dunia, Indonesia Tuan Rumah Konferensi Internasional Mangrove 2017. http://pressrelease.id/release/milik i-23-ekosistem-mangrove-duniaindonesia-tuan-rumah-konferensiinternasional-mangrove-2017. Diakses 2 agustus 2017

Gaspersz V. 1991. Metode Perancangan Percobaan. CV. Armico. Bandung.

Halidah. 2009. Pengaruh Tinggi Genangan Dan Jarak Tanam Terhadap Pertumbuhan Anakan Rhizophora Mucronata Lam. Di Pantai Barat Sulawesi Selatan. Balai Penelitian Kehutanan Manado.

Hutahaean EE, Kusmana C, Dewi HR. 1999. Studi Kemampuan Tumbuh Anakan Mangrove Jenis Rhizophora mucronata,
Bruguiera gimnorrhiza dan Avicennia marina Pada Berbagai Tingkat Salinitas. Jurnal Manajemen Hutan Tropika 1: 7785.

Kairo JG, Guebas FD, Bosire J, Koedam N. 2001. Restoration and Management of Mangrove Systems - a lesson for and from the East African Region. South African Journal of Botany 2001, 67: 383-389.

Kusmana C, Istomo, Wibowo C, Wilarso BR, Zulkarnaen S, Tiryana T, Sukardjo S. 2008. Manual Silvikultur Mangrove di Indonesia. Korea International Cooperation Agency (KOICA). The Rehabilitation Mangrove Forest and Coastal Area damaged by Tsunami in Aceh Project. Jakarta.

Kusmana C, Kalingga M, Syamsuwida D. 2011. Pengaruh Media Simpan, Ruang Simpan dan Lama Penyimpanan Terhadap Viabilitas Benih Rhizophora Stylosa Griff. Jurnal Silvikultur Tropika. Vol. 03: $82-87$.

Kusmana C, Istomo, Purwanegara T. 2014. Teknik Guludan Sebagai Solusi Metode Penanaman Mangrove Pada Lahan Yang Tergenang Air Yang Dalam. Risalah Kebijakan Pertanian dan Lingkungan. Vol.1 No.3, Desember 2014: 165-171. ISSN: 2355-6226.

Kustanti, A. 2011. Manajemen Hutan Mangrove. IPB Press. Bogor.

LPT. 1983. Kriteria Sifat Kesuburan Tanah. https://mafiadoc.com/queue/kriteri a-penilaian-sifat-kimiatanah_59d44af31723dd062efc538 
5.html. Diakses 4 September 2017.

Nybakken JW. 1992. Biologi Laut Suatu Pendekatan Ekologi. PT. Gramedia Pustaka Utama. Jakarta.

Onrizal. 2005. Adaptasi Tumbuhan Mangrove Pada Lingkungan Salin dan Jenuh Air. e-USU Repository. Universitas Sumatera Utara. Medan.

Setyawan AD, Winarno K, Purnama PC. 2004. Review: Ekosistem Mangrove di Jawa : Restorasi.
Biodiversitas. Vol.5 No.2: 105118.

Sutanto R. 2005. Dasar-Dasar Ilmu Tanah Konsep dan Kenyataan. Penerbit Kanisius. Yogyakarta.

Syah C. 2011. Pertumbuhan Tanaman Bakau (Rhizophora mucronata) Pada Lahan Restorasi Mangrove di Hutan Lindung Angke Kapuk Provinsi DKI Jakarta. Tesis. Program Pascasarjana. Institut Pertanian Bogor. Bogor. 